
https://doi.org/10.30534/ijeter/2020/728102020

\title{
The Development of Web-Based Clinical Information in Polyclinic at University of Lampung
}

\author{
Rasmi Zakiah Oktarlina ${ }^{1}$, Aristoteles ${ }^{2}$, Sarifah $_{\text {Mudaim }^{3}, \text { Anggi Angraeni }^{2} \text {, Ety Apriliana }}{ }^{3}$ \\ ${ }^{1}$ Department of Pharmacology and Pharmacy, Medical Faculty, University of Lampung, Indonesia, \\ rasmi.zakiah@fk.unila.ac.id \\ ${ }^{2}$ Computer Science Program, Mathematics, and Natural Science Faculty, University of Lampung, Indonesia \\ ${ }^{3}$ Department of Microbiology and Parasitology, Medical Faculty, University of Lampung
}

\begin{abstract}
A medical record is a file containing notes and documents regarding the patient's identity, examination, treatment, actions, and services that have been provided to patients. The medical record recording activity carried out by the University of Lampung Polyclinic management was not optimal. The problems that occur are the absence of complete medical record data and difficulty finding medical record files. Meanwhile, the inventory contains a list of medicines used at the polyclinic, including price, quantity, type, and condition. The inventory system usually consists of a medicine receiving system, a medicine purchase system, and a warehouse system. This system must provide inventory information such as medicine dispensing information, medicine purchase, medicine receipt, and other information quickly and accurately. This study aimed to establish a clinical information system at the University of Lampung polyclinic BP to facilitate every employee in need of medicine or medical equipment. With this information system, it is hoped that it can further assist in processing medical record data and medicine inventories used by polyclinic employees to do work. The stages in this research were collecting research data by observing the polyclinic to collect system requirements so that the business processes that will be applied to the system are formed, and the second stage was making database design, a coding program, integration followed by installation, running, and testing the program. This study's results are expected to provide benefits in providing information about medical records and medicine inventories in facilitating the work of polyclinic employees.
\end{abstract}

Keywords: Information system, Medical Information, Inventory, Polyclinic.

\section{INTRODUCTION}

For an organization or agency, information systems and information of technology (SI/TI) are essential because (SI/TI) functions as a supporting tool for improving performance and making decisions based on the information. Processing data quickly, precisely, and efficiently is an important thing that is needed for any organization or agency to increase work productivity, time, and cost $[1,2]$. The use of a computer due to technology and information is currently widespread and can be reached by the community not only limited to the work environment but also in the health care environment [3].

The use of health service is one of the essential needs. Along with increasing public awareness of the importance of health, one of the institutions that deal with health service issues is an institution in the polyclinic form. Polyclinic is one of the community services unit engaged in the health sector. A polyclinic that offers health facilities that are devoted to outpatient care. The polyclinic's primary purpose is to serve patients who will seek treatment, and it is the main activity so that the provision of information that can support and improve the system is needed [4].

At this time, the University is one of the places that provide health care facilities for the academic community and the general public. One of the student welfare services in terms of maintaining physical welfare is realized by the University of Lampung (Unila) to provide a student health polyclinic.

Polyclinic of the University of Lampung, as a service unit engaged in the health sector, must have a medicine inventory information system.inventory is a list of items used in the company or office, including price, quantity, type, and condition. The inventory system usually consists of a system for receiving things, purchasing things, and a warehouse [5]. Electronic Medical Record or Electronic Health Record is an activity to computerize health records contents starting from collecting, processing, analyzing, and presenting the data related to health services [6]. The development of a digital information system can significantly reduce the workforce required, speed up medical records processing, and reduce the space allocated to store thousands of medical record papers [7].

The management and storage of medical record data and medicine inventory in the University of Lampung's polyclinic are still done manually, and the preparation of reports is only recorded on paper, not neatly arranged, causing constraints in employee performance. Manurut [8], in cases like this, several obstacles have not been resolved from pharmacists 
who want to see the available medicines to leaders who want to know the number of sales and existing stocks.

To solve the problem, the use of a computerized information system can be the right solution. With the clinical information system, the medical supplies will be recorded clearly, so it is more accurate and can be accounted for $[9,10]$. The database central can help record, check medicine supplies, and order medicine from the supplier warehouse to not include the excess in ordering medicines. All incoming and outgoing medicine in the warehouse can be identified without disturbing errors in the medicine supply process later $[11,12]$. Those things then become the basis for developing a web-based clinical information system at BP Polyclinic of the University of Lampung, making it easier for every employee who needs medicine or medical equipment. With this information system, it is hoped that it can further help the process of medicine inventory data used by polyclinic employees to do their work.

\section{METHODS}

\subsection{System Development Methods}

The development method used in this research is the Extreme Programming method. The stages carried out in the Extreme Programming method are shown in Figure 1. The planning stages included deepening the business process and system planning. System planning included the creation of the Unified Modelling Language.

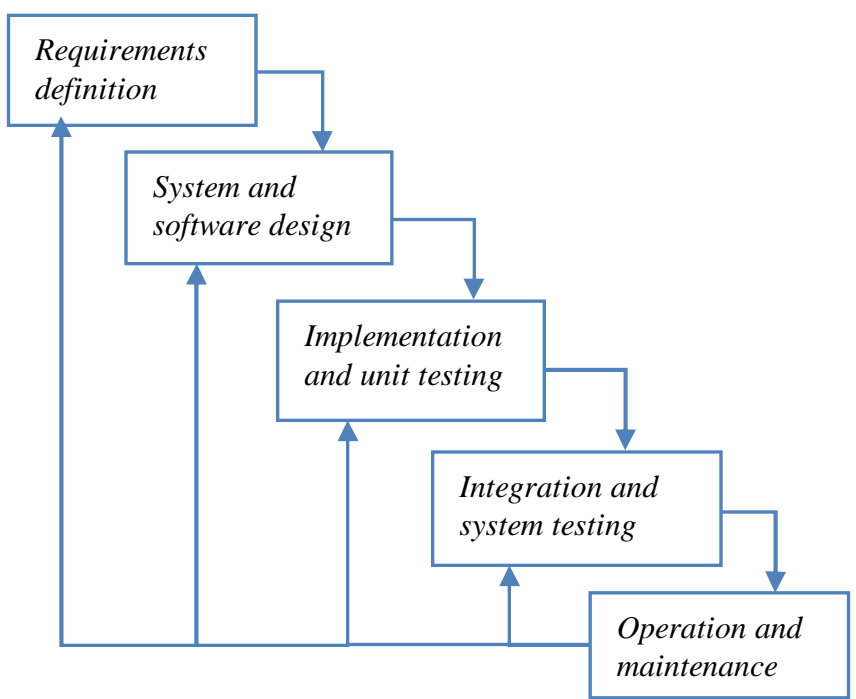

Figure 1: Method Cascade

\subsection{System Analysis}

This stage was carried out by communicating with the supervisor about how the polyclinic desired information system can help employees work. In this step, the system design stage and interface design were carried out. This system design used use case diagram analysis and system design with object-oriented methodology adopting the widespread use of the language "Object-Oriented Programming" (OOP) [13].

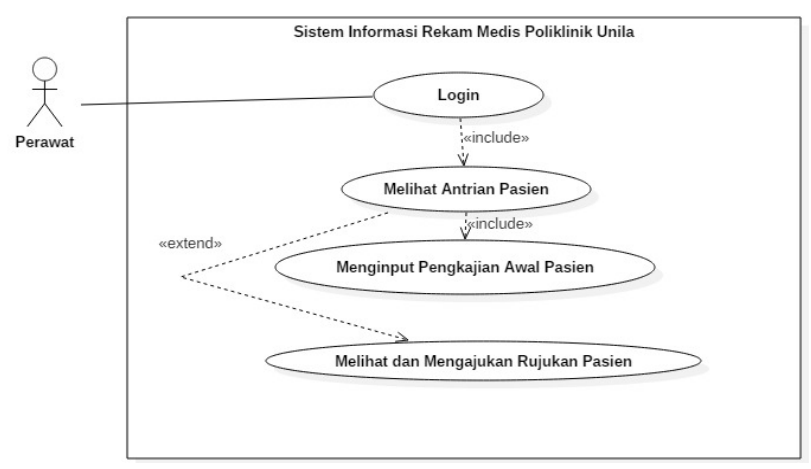

Figure 2: Use Case Diagram of Nurse Users

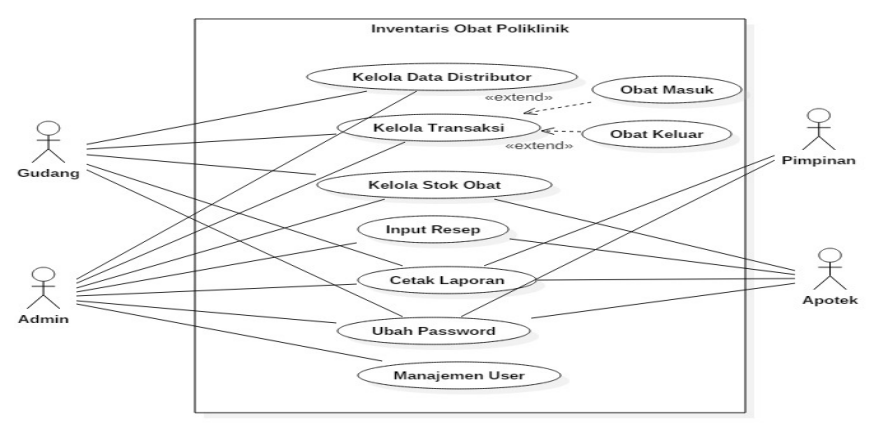

Figure 3: Use Case Diagram of Inventory

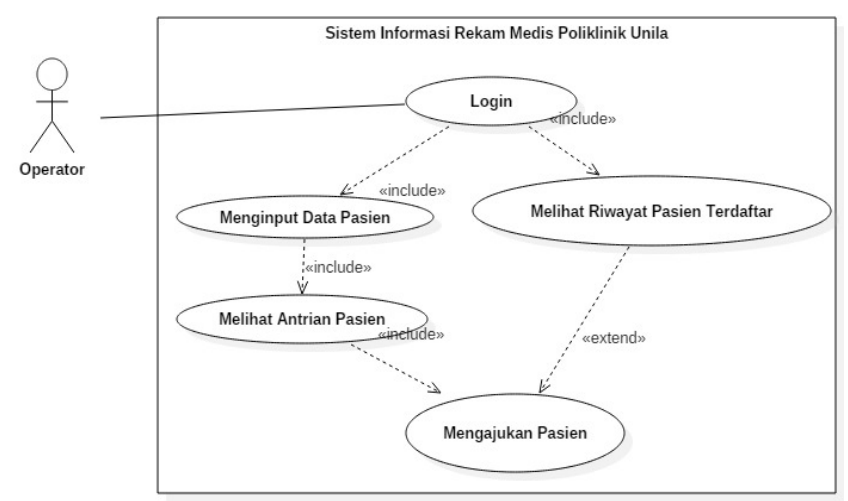

Figure 4: Use Case Diagram of Operator User

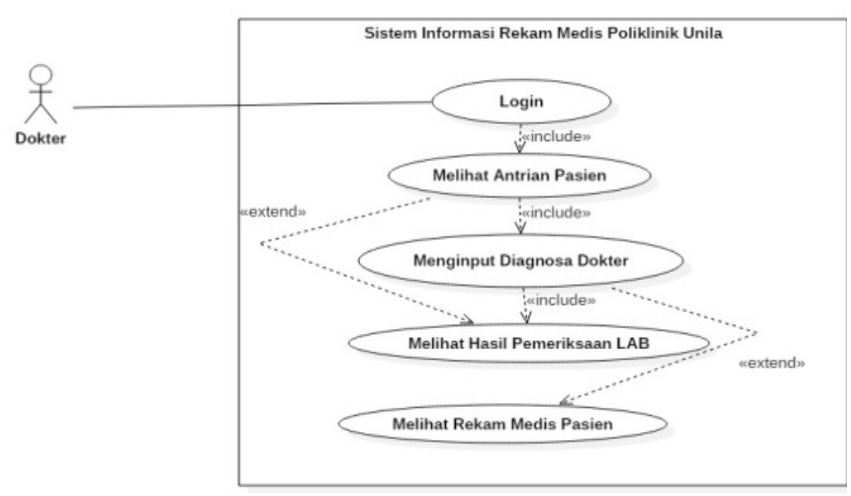

Figure 5: Use Case Diagram of Doctor User 


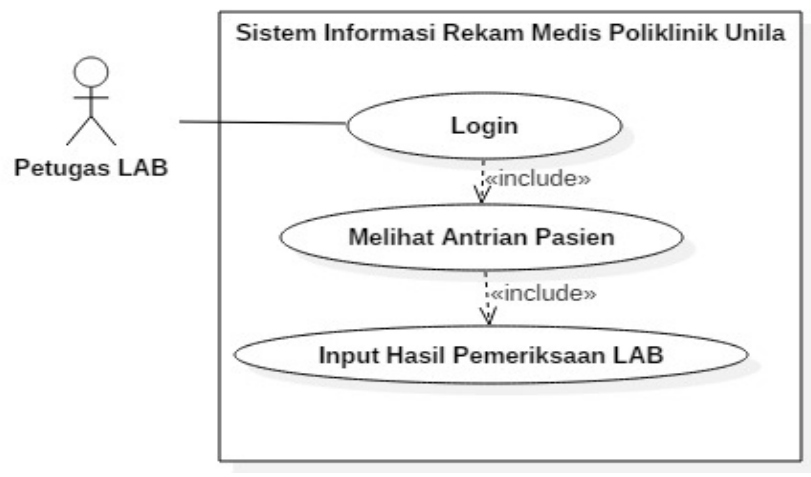

Figure 6: Use Case Diagram of Lab User

\subsection{System Design}

This stage was done by designing the interface (design interface). Interface design is a process of describing how a system interface is formed.

\subsection{Implementation}

In this stage, the programming (coding) will be carried out; the program development stage was carried out by implementing the system's problems. The programming (coding) process used the PHP programming language, making designs with HTML and MySQL for making the database.

\subsection{Testing Stage}

This study used a system testing with a black-box approach. System testing is a test carried out on the system as a whole. The black box approach was a testing approach to determine whether all software functions have adequately run by defined design results [14].

\section{RESULTS AND DISCUSSION}

\subsection{Results}

The next stage was carried out after the planning and design stage, namely the coding stage. In the coding process, the designed interface design can be implemented in the interface system.

\subsection{Implementation}

Implementation is the application of the results of the analysis and system design that has been made. The following are the Clinical Information System results at the Web-Based Polyclinic BP at the Polyclinic of the University of Lampung.

\section{A. Home Menu}

The home menu is the display that will appear for the first time when the user successfully logs into the Medicine Inventory Information System at the Polyclinic of the University of Lampung. The home page display can be seen in Fig 7.

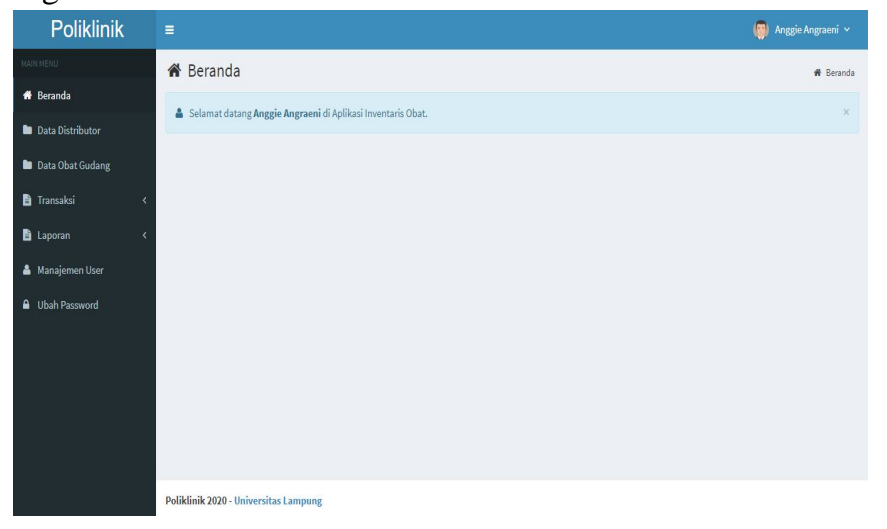

Figure 7: The Interface of Home Menu

\section{B. Interface of New Patient Data Input Form by Operator}

In Fig 8, the nurse will fill in the new patient data that has never arrived before. The data entered is the personal data of the patient. After the data is inputted, the system will create a column of medical records for the patient.

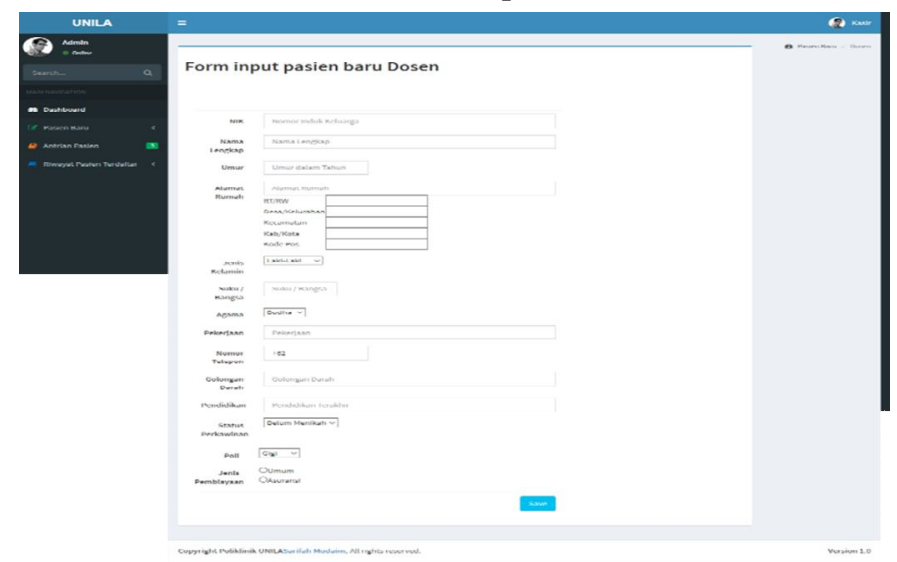

Figure 8: The Interface of New Patient Data Input Form by Operator

\section{Interface of Patient Queue}

Fig. 9 is a display of the patient's queue. The queue display is available in almost all users except the manager level. The queue display is only slightly different in the cashier section, called "Active bill," while on the doctor's page on the queue, there is a button "Finish lab inspection."

\section{Interface of Form Input of Supporting Examination Results by the Lab}

The display in Fig. 10 is found in the lab user, where the data that must be checked is the data sent by the doctor, and 
the lab staff will input the examination result data, which will be read on the doctor's display.

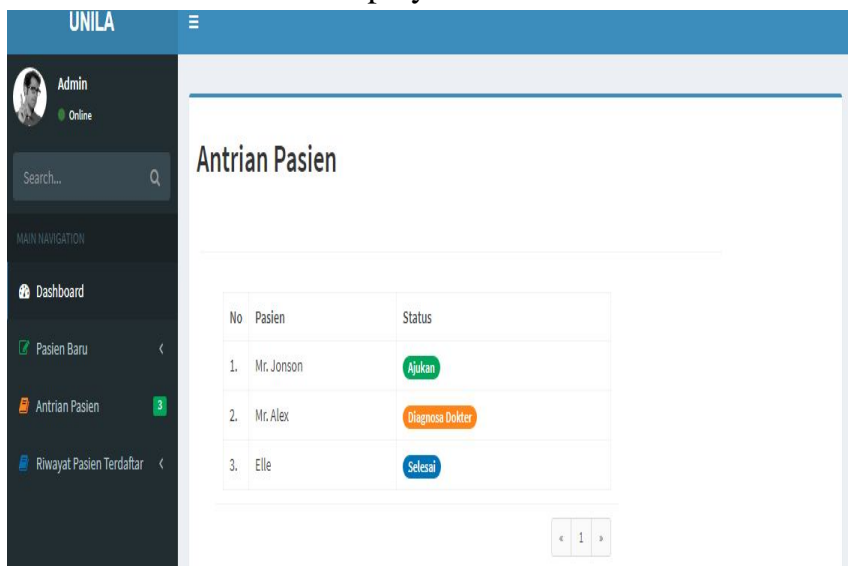

Figure 9: The Interface of Patient Queue

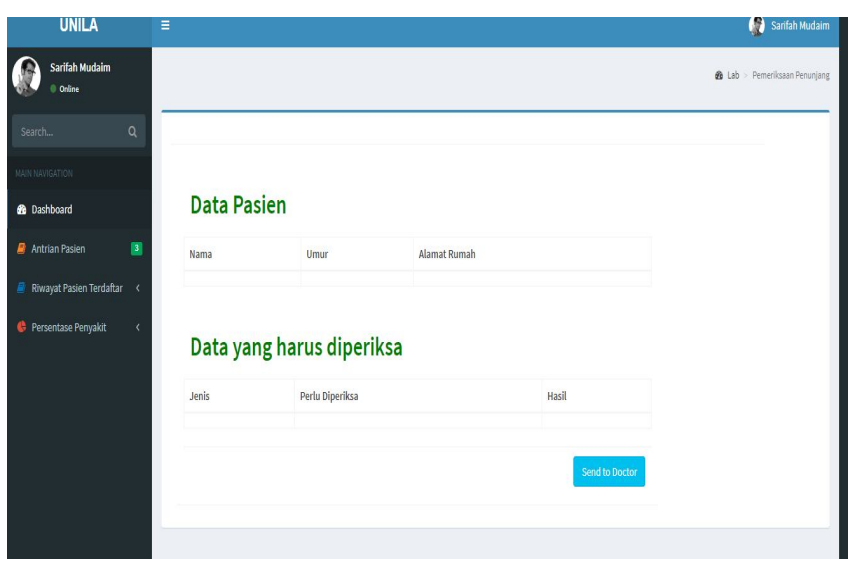

Figure 10: The Interface of Form Input of Supporting Examination Results

\section{E. Manage Distributor Menu}

Manage distributor menu is a page that provides functions to view, edit, and delete distributor data. On this page, the user inputted the data on the add distributor data menu will be displayed, which then the user can edit and delete the selected distributor data. The display of the distributor data management page can be seen in Fig 11.

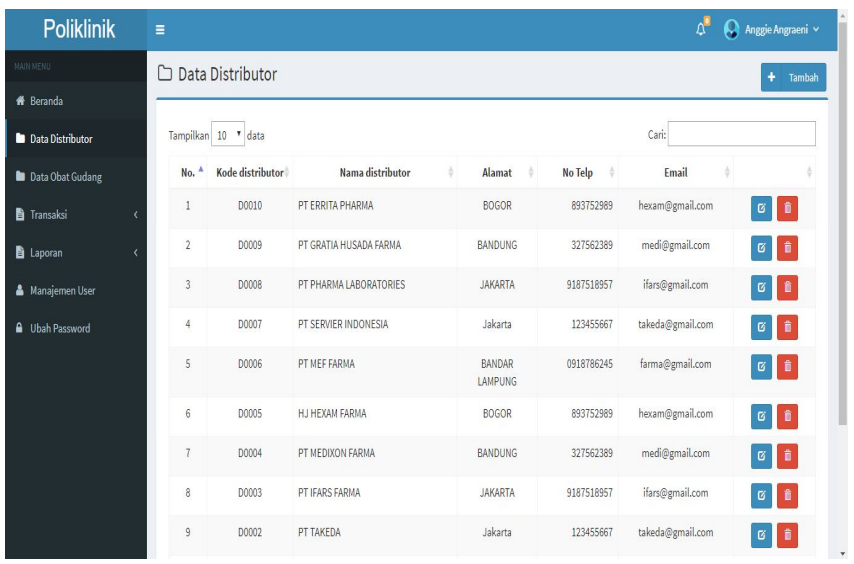

\section{F. Manage Medicine Data menu}

Manage the medicine data menu is a page that provides the functions of viewing and adding medicine data forms. On this page, the data that has been inputted by the warehouse in the add medicine form menu will be displayed, which then the warehouse can add data for the selected medicine to be entered into the pharmacy. The display of the medicine data page can be seen in Fig 12 .

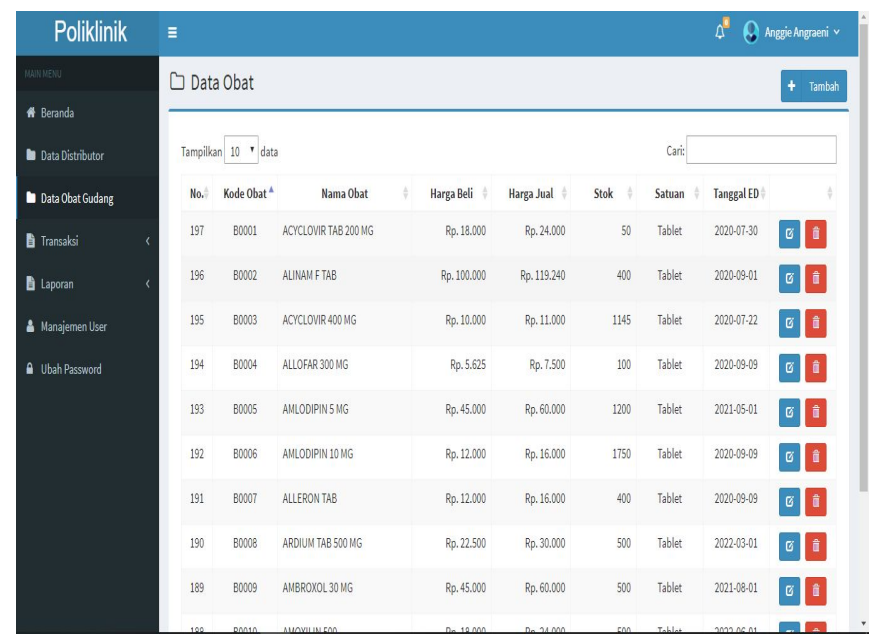

Figure 12: The Interface of Manage Medicine Data Menu

\section{G. Manage Medicines Exit Menu}

The manage medicines exit menu is a page that provides the functions to view, print, and retrieve medicines from the warehouse to be put into the pharmacy. On this page, the data that has been inputted by the warehouse on the medicine collection menu will be displayed, which then the warehouse can view and print the selected outgoing medicine data. The display of the managing outgoing medicine data page can be seen in Fig 13.

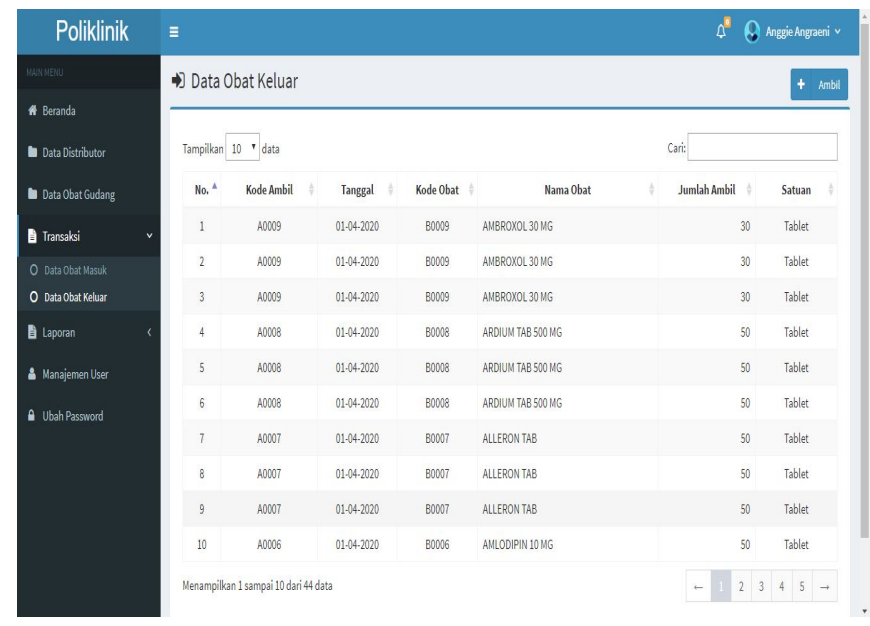

Figure 13: The Interface of Manage Medicines Exit Menu

Figure 11: The Interface of Manage Distributor Menu 


\section{H. Manage Incoming Medicines Menu}

Manage incoming medicines menu is a page that provides the functions of viewing and increasing the incoming medicine stocks from the distributor to the warehouse. The incoming medicine data will be displayed on this page, which then the warehouse can add the selected incoming medicine stock. The display of the incoming medicine data management page can be seen in Fig 14 .

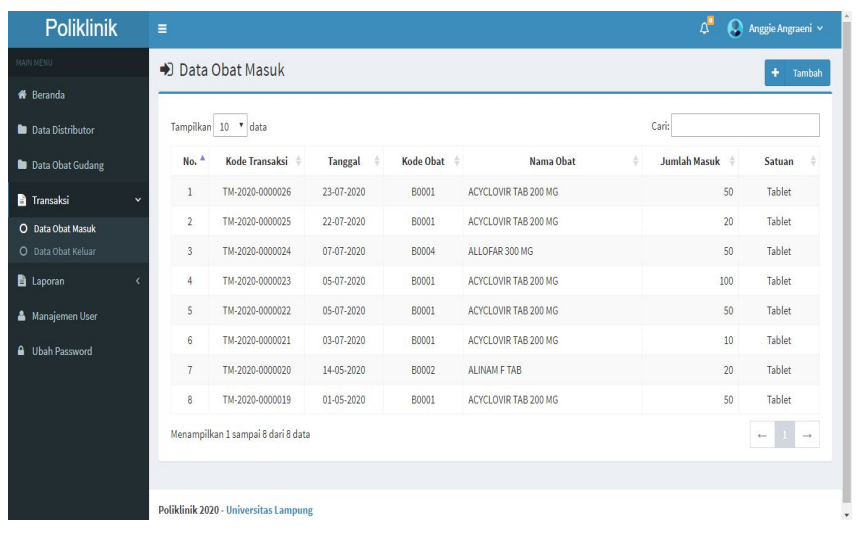

Figure 14: The Interface of Manage Incoming Medicine Menu

\subsection{System Testing}

The system was developed using black-box testing techniques with The Waterfall Method. The waterfall is a systematic and sequential approach to software development, starting with the specification of user requirements, then planning, modeling, construction, and handing over the software users, ending with outgoing support for the software [15]. Blackbox testing allows a developer to get a series of input conditions that entirely use the functional requirements [16]. This stage determines the testing criteria discussed based on the object to be tested in existing forms [17].

\section{CONCLUSION}

Our research shows that the medicine inventory system is as follows: 1) Facilitate the polyclinic recording and archive patient medical records and facilitate communication between employees who handle the patients. Making this system produces medical records in the form of pdf and patient payment receipts; 2) Makes it easy to check incoming or outgoing medicine stocks, stock medicine warnings, medicine expiration warnings so that there are no mistakes in recording stocks and ordering from warehouses to suppliers; 3) Support and accelerate decision making and officers can immediately see the shortage of medicine stocks in the Polyclinic of University of Lampung automatically.

\section{ACKNOWLEDGEMENT}

We wish to thank to the University of Lampung - Research Institutions and Community Service (LPPM-Unila) for supporting this research.

\section{REFERENCES}

1. Rahmawati. Sistem Informasi Inventaris Stok Barang pada CV Artha Palembang, S. Kom. thesis, UIN Raden Fatah, Palembang, 2017.

2. G. Wang, Alamas, N., Anggraeni, M. The use of things and big data to improve customer data in insurance company, International Journal of Emerging Trends in Engineering Research, vol. 7, no. 12, pp. 756-761, 2019.

3. Permana P. A. Y. Rancang bangun sistem informasi klinik praktik dokter berbasis web, J. Teknologi Informasi dan Komputer, Vol. 1, pp. 127-133, 2015.

4. R. Bagaskara, E. Inder, W. A. Syafei, and R. R. Isnanto. Perancangan sistem informasi poliklinik. Transient: Jurnal Ilmiah Teknik Elektro, vol. 1, no. 4, pp. 348-354, 2012.

5. Susanto A. Pengembangan Sistem Informasi Inventaris pada PT. Dwi Warna Inti Sejahtera. UIN Syarif Hidayatullah, Jakarta, 2010.

6. Rustiyanto E. Etika Profesi Perekam Medis \& Informasi Kesehatan. Yogyakarta, Indonesia: Penerbit Graha Ilmu, 2009.

7. P. Yuliartanto, A. F. Rochim, I. P. Windasari. Pengembangan sistem informasi rekam medis untuk dinas kabupaten grobogan, Jurnal Teknologi Informasi dan Komputer, vol. 2, no. 3, pp. 203-208, 2014.

8. D. Puspitasari. Sistem Informasi Persediaan Obat Berbasis Web pada Klinik dan Apotek Hermantoni Karawang, S. Kom. thesis, AMIK BSI, Bekasi, 2017.

9. Firdiansyah. Analisa dan Perancangan Sistem Informasi Persediaan Obat pada Poliklinik Bappenas dengan Metodologi Berorientasi Obyek, S. Kom. thesis, Universitas Budi Luhur, Jakarta, 2014.

10. Sahana D. S., Dayanand, L. N., Nida K. G., Deepak, S. S. Software defined network evolution: a quality viewpoint for enterprise management, International Journal of Emerging Trends in Engineering Research, vol. 8, no. 7, pp. 3403-3409, 2020.

11. M. Siti. Rancang Bangun Sistem Informasi Inventaris Obat pada Rumah Sakit Jiwa Tampan Berbasis Web, S. Kom. thesis, UIN Suska, Riau, 2018.

12. Sommerville. Software Engineering, 9th ed. Boston, USA: Pearson Education Inc, 2011.

13. Adi N. Rekayasa Perangkat Lunak Menggunakan UML \& Java. Yogyakarta, Indonesia: Penerbit Andi, 2009.

14. Sulistyanto H., Azhari, S. N. Urgensi Pengujian pada Kemajemukan Perangkat Lunak dalam Multi Perspektif, Komuniti: Jurnal Komunikasi dan Teknologi Informasi, vol. 6, no. 1, pp. 65-74, 2017. 
Rasmi Zakiah Oktarlina et al., International Journal of Emerging Trends in Engineering Research, 8(10), October 2020, 7087 - 7092

15. Pressman R. S. Software Engineering: A Practitioner's Approach, 7th ed. Yogyakarta, Indonesia: Penerbit Andi, 2012.

16. Pressman R. S. Rekayasa Perangkat Lunak. Yogyakarta, Indonesia: Andi Offset, 2012.

17. Busono P. Testing \& Implementasi. Jakarta, Indonesia: Pusat Pengembangan Bahan Ajar UMB, 2009. 